\title{
Age-dependent changes in diurnal thermoregulatory responses of rabbits during the early-rainy season \\ ${ }^{1} *$ Yaqub, L. S., ${ }^{1}$ Ezekiel, A. E., ${ }^{1}$ Umar, A., ${ }^{1}$ Habibu, B., ${ }^{2}$ Aliyu, H. and ${ }^{1}$ Kawu, M.U. ${ }^{I}$ Department of Veterinary Physiology, Ahmadu Bello University, Zaria

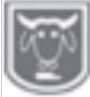 \\ ${ }^{2}$ Department of Veterinary Pharmacology and Toxicology, Ahmadu Bello University, Zaria \\ Abstract \\ *Corresponding author: yaqvet@gmail.com; +2348033875044
}

High relative humidity and ambient temperature are one of the constrains to efficient thermoregulatory responses of rabbits in the tropics during the early-rainy season. The study investigated the effect of age on diurnal thermoregulatory responses in rectal (RT), ear (ET) and skin temperatures (ST) of rabbits during the early-rainy season. Seventeen apparently healthy rabbits were divided into three groups of 5 weaners, 6 growers and 6 adults. Physiologic parameters of RT, ET and ST of the rabbits were recorded concurrently with thermal environmental parameters of dry-bulb (DBT) and wet-bulb readings, at 07:00, 10:00, 13:00, 16:00 and 19:00 h, once per week for three weeks. Result revealed that RT, ET and $S T$ were higher in adult compared to weaner or grower rabbits. The RT and ST were higher in adult than weaner rabbits at 13:00, 16:00 and 19:00 h. The ET was higher in adult than the weaner rabbits at 07:00 h. However, there was no significant $(P>0.05)$ difference in physiological parameters between the weaner and grower rabbits. The DBT positively correlated with ET in all age groups (Weaners $r=0.960, P<0.01$; Growers $r=0.975, P<$ 0.01; Adult $r=0.942, P<0.05)$. The ST of weaner $(r=0.904 ; P<0.05)$ and grower $(r=$ 0.997; $P<0.01)$ rabbits positively correlated with DBT. It was concluded that there was agedependent effect on diurnal thermoregulatory responses and RHnegatively impacted on heat dissipation ability of the rabbits. It is recommended that adequate ventilation should be provided in rabbit house to reduce the negative impact of high $R H$ on heat dissipation ability of rabbits during the early-rainy season.

Keywords: Diurnal changes, Early-rainy season, Rabbits, Ear temperature, Rectal temperature and Skin temperature,

\section{Des Changements dépendant de l'âge dans les réponses thermorégulatrices diurnes des lapins au début de la saison des pluies}

\section{Résumé}

L'humidité relative élevée et la température ambiante sont l'une des contraintes aux réponses thermorégulatrices efficaces des lapins sous les tropiques pendant la saison des pluies. L'étude a étudié l'effet de l'âge sur les réponses thermorégulatrices diurnes dans les températures rectales (RT), de l'oreille (ET) et de la peau (ST) des lapins pendant la saison des pluies précoces. Dix-sept lapins apparemment en bonne santé ont été divisés en trois groupes de 5 sevrés, 6 cultivateurs et 6 adultes. Les paramètres physiologiques de RT, ET et ST des lapins ont été enregistrés en même temps que les paramètres environnementaux thermiques des lectures de bulbe sec (DBT) et d'ampoule humide, à 07:00, 10:00, 13:00, 16:00 et 19:00 h, une fois par semaine pendant trois semaines. Le résultat a révélé que rt, ET et ST étaient plus élevés chez les adultes par rapport aux lapins sevrés ou de producteur. Le RT et le ST étaient plus élevés chez les lapins adultes que chez les lapins sevrés à $13 \mathrm{~h}, 16 \mathrm{~h}$ et 19 h. L'ET était plus élevé chez les adultes que chez les lapins sevrés à $7 \mathrm{~h}$. Cependant, il n'y 
avait aucune différence significative $(P>0,05)$ dans les paramètres physiologiques entre le sevreur et les lapins de producteur. Le DBT était en corrélation positive avec l'ET dans tous les groupes d'âge (Sevreurs $r=0,960, P<0,01$; Producteurs $r=0,975, P<0,01$; Adulte $r=$ 0,942, $P<0,05)$. Le ST du sevreur $(r=0,904 ; P<0,05)$ et producteur $(r=0,997 ; P<0,01)$ lapins positivement corrélés avec DBT. On a conclu qu'il y avait un effet dépendant de l'âge sur les réponses thermorégulatrices diurnes et que l'HR avait un impact négatif sur la capacité de dissipation thermique des lapins. Il est recommandé d'assurer une ventilation adéquate dans la maison du lapin afin de réduire l'impact négatif d'une HR élevée sur la capacité de dissipation thermique des lapins pendant la saison des pluies.

Mots-clés: Changements diurnes, Saison des pluies précoces, Lapins, Température de l'oreille, Température rectale et température de la peau

\section{Introduction}

Rabbit is an economic livestock that could be used to bridge gap in dietary protein intake, especially in most developing countries of the tropics (Marai et al., 2002). However, one of the constraints to efficient and rapid multiplication of rabbit in these countries is the prevailing meteorological parameters of high ambient temperature during the dry season and high relative humidity and ambient temperature during the early-rainy season (Marai et al., 2002; Ferraz et al., 2019). Early-rainy season (May-June) is a transition period from hotdry period to rainy season. The prevailing ambient temperature and relative humidity are often above the thermoneutral zone for rabbit. Rabbits display instinctive behavior of burrowing underground to escape from predators and to avoid high ambient temperature. Rabbits in captivity are denied this inherent thermoregulatory behaviour, hence, they are highly susceptible to heat stress (Lukefahr and Ruiz-feria, 2003). Rabbits are also highly sensitive to very low relative humidity $(<55 \%)$, especially when the ambient temperature is in the range of rabbit core body temperature. In such conditions, the latent heat of dissipation becomes inefficient, because it is dependent on the relative humidity (Ferraz et al., 2019). Unfortunately, this is a common situation in tropical climate during the early-rainy season. In addition to the meteorological factors, variations can occur due to age and body weight (Keim et al.,
2002). Body temperature are among the physiological data that are sensitive to minute change in livestock and most related to important number of varied functions of the body. The best parameter to assess for stress conditions in rabbits is the ear temperature, due to vasomotor control of blood. Though the general effect of prevailing ambient temperature on the growth performance of growing rabbits in temperate environment have been well documented (Amici et al., 1998; Barbosa et al.,1992; Hermes et al.,1999; Ogunjimi et al., 2008). However, these studies were carried out under controlled conditions (Zeferino et al., 2011). Similarly, previous investigators have reported diurnal variation in rectal temperature of rabbit during the hot-dry season in the same environment (Ayo et al., 2006). However, there is a paucity of information in the available literature on the effect of age of rabbit on diurnal variations in rectal, skin and ear surface temperatures during the early-rainy season in the tropics. Such information, if generated, may provide insight into thermoregulatory mechanism of rabbits of different age groups during high ambient temperature and relative humidity characteristic of the early-rainy season in the tropics.

\section{Materials and methods \\ Animals and management}

The experiment was performed during the 
animal house of the Department of Veterinary Public Health and Preventive Medicine, Faculty of Veterinary Medicine, Ahmadu Bello University, Zaria, located in the Northern Guinea Savannah zone of Nigeria. Seventeen (17) apparently healthy New Zeland rabbits, weighing between 0.7 $\mathrm{kg}-2.9 \mathrm{~kg}$ were used in the present study. The rabbits were preconditioned for two weeks to the experimental procedure. They were individually housed in a locally fabricated house measuring $50 \times 25 \mathrm{~cm}$. The rabbits were provided with feed and water ad-libitum. Rabbits were allotted to three groups of 7 growers (6-12 months), 6 weaners (4-6 months) and 6 adults (12 months and above). Rectal temperature was determined with the aid of digital clinical rectal thermometer (Trio-Digitatherm, Hamburg, Germany), ear and skin surface temperatures were determined using handheld infrared thermometers (Raycon, China). These parameters were determined once a week for three consecutive weeks, three-hourly, starting at 07:00 am - 07:00 $\mathrm{pm}$. Wet and dry bulb temperatures of the experimental room were recorded threehourly during the determination of physiological parameters using wet and dry-bulb hygrometer (Brannan ${ }^{\circledR}$, San Diego, California, U.S.A). Relative humidity values were calculated from the dry and wet-bulb temperature values using conversion tables published by the Bulletin of the U.S weather Bureau No. 1071.

Temperature-humidity index was calculated using the formula (Marai et al., 2002):

$\mathrm{THI}=\mathrm{DB}^{\circ} \mathrm{C}-\left[(0.31-0.31 \mathrm{RH})\left(\mathrm{DB}^{\circ} \mathrm{C}-\right.\right.$ 14.4)]

Where $\mathrm{THI}=$ Temperature-humidity index

$\mathrm{DB}=$ Dry-bulb temperature

$\mathrm{RH}=$ Relative humidity

Determination of rectal, ear and skin surface temperatures

The rectal temperature was determined by inserting a digital clinical rectal thermometer for about 1-2 minutes into the rectum of each rabbit, until a beep sound was produced, indicating the end of reading. Ear and skin surface temperatures were determined by positioning the infrared thermometer about $3 \mathrm{~cm}$ from the target spot. The skin around the inguinal area was used for skin surface temperature. The readings were taken after the infrared thermometer indicated a stable value.

\section{Experimental design and data analysis}

All values were expressed as mean ( \pm SEM). One Way Analysis of Variance was used to determine the differences between the groups, while, Repeated Measures Analysis of Variance followed by Turkey's post-hoc test was used to determine variations in thermoregulatory parameters within group. Relationships between meteorological and physiological parameters were determined using Pearson's correlation. The statistical package used was, graph pad software, San Diego, California, U.S.A, version 5.0 was used and values of $\mathrm{P}<0.05$ were considered significant.

\section{Results}

Meteorological parameters during the study period

The prevailing dry-bulb temperature (DBT) gradually rose during the study period and attained the highest value at 16:00 $\mathrm{h}(32.17$ $\pm 0.93{ }^{\circ} \mathrm{C}$ ) (Table 1). The value of DBT recorded at 07:00 $\mathrm{h}$ was significantly lower than the values obtained at 13:00 h, 16:00 h and 19:00 h. While that at 10:00 h was significantly lower in comparison to values at 13:00 $\mathrm{h}, 16: 00 \mathrm{~h}$ and 19:00 $\mathrm{h}$. The highest temperature-humidity and relative humidity were recorded at 16:00 h $(29.87 \pm$ 0.59 ) and 7:00 h (72\%), respectively (Table 1). 
Table 1: Mean ( \pm SEM) meteorological parameters during the study period

\begin{tabular}{llll}
\hline Time of the day $(\mathbf{h})$ & $\begin{array}{l}\text { Dry bulb temperature } \\
\left({ }^{\circ} \mathbf{C}\right)\end{array}$ & Relative humidity $(\%)$ & $\begin{array}{l}\text { Temperature-humidity } \\
\text { index }\end{array}$ \\
\hline $07: 00$ & $28.83 \pm 0.73^{\mathbf{a}}$ & $75.00 \pm 4.36$ & $27.69 \pm .0 .48$ \\
$10: 00$ & $29.83 \pm 1.01^{\mathbf{b}}$ & $69.00 \pm 6.61$ & $27.53 \pm 1.42$ \\
$13: 00$ & $31.33 \pm 1.09^{\mathbf{c}}$ & $69.00 \pm 10.12$ & $29.64 \pm 0.49$ \\
$16: 00$ & $32.17 \pm 0.93^{\mathbf{c}}$ & $66.33 \pm 9.33$ & $29.87 \pm 0.59$ \\
$19: 00$ & $30.73 \pm 1.19^{\mathbf{c}}$ & $66.33 \pm 4.63$ & $28.45 \pm 0.94$ \\
\hline
\end{tabular}

$\overline{\mathrm{a}, \mathrm{b}, \mathrm{c}}$ superscripts within the same column with different superscripts are signifficantly different $(\mathrm{P}<0.05)$

\section{Effect of age on diurnal variation in rectal temperature $\left({ }^{\circ} \mathrm{C}\right)$ of rabbits}

The highest mean RT was recorded at 07:00 $\mathrm{h}$ irrespective of the age of rabbits and this was significantly higher $(\mathrm{P}<0.05)$ in comparison to value obtained at 13:00 $\mathrm{h}$ in weaners and at 13:00 h, 16:00 $\mathrm{h}$ and 19:00 $\mathrm{h}$ for growers. There was no significant $(\mathrm{P}>$
0.05 ) diurnal variation in RT of adult rabbits (Table 2). The highest RT was recorded in adult rabbits regardless of the hour of the day and was significantly higher $(\mathrm{P}<0.05)$ compared to values obtained in other age groups at 13:00 h, 16:00 $\mathrm{h}$ and 19:00 $\mathrm{h}$ (Table 2).

Table 2: Effect of age on diurnal variation in rectal temperature $\left({ }^{\circ} \mathrm{C}\right)$ of rabbits during the early-rainy season

\begin{tabular}{llll}
\hline Hour of the day & Weaners & Growers & Adults \\
\hline $07: 00$ & $37.98 \pm 0.17^{\mathbf{x}}$ & $38.08 \pm 0.12^{\mathbf{x}}$ & $38.53 \pm 0.22$ \\
$10: 00$ & $37.61 \pm 0.19^{\mathbf{a}}$ & $37.67 \pm 0.15$ & $38.08 \pm 0.27$ \\
$13: 00$ & $37.28 \pm 0.15^{\mathbf{a}, \mathbf{y}}$ & $37.19 \pm 0.17^{\mathbf{a}, \mathbf{y}}$ & $38.03 \pm 0.13^{\mathbf{b}}$ \\
$16: 00$ & $37.76 \pm 0.15^{\mathbf{a}}$ & $37.38 \pm 0.15^{\mathbf{b}, \mathbf{y}}$ & $38.04 \pm 0.15^{\mathbf{c}}$ \\
$19: 00$ & $37.43 \pm 0.20^{\mathbf{a}}$ & $36.85 \pm 0.16^{\mathbf{b}, \mathbf{y}}$ & $37.99 \pm 0.19^{\mathbf{c}}$ \\
\hline
\end{tabular}

$\mathrm{a}, \mathrm{b}, \mathrm{c}=$ row with different superscript letters are significantly different $(\mathrm{P}<0.05)$

$\mathrm{x}, \mathrm{y}=$ column with different superscript letters are significantly different $(\mathrm{P}<0.05)$

Effect of age on diurnal variation in skin surface temperature $\left({ }^{\circ} \mathrm{C}\right)$ in rabbits

The ST in all the groups gradually increased as the hour of the day progresses and a slight decrease at 19:00 $\mathrm{h}$. The ST in adult was significantly $(\mathrm{P}<0.05)$ higher compared to the weaner or grower rabbits. The least ST was recorded in all the groups at 07:00 $\mathrm{h}$ and significantly $(\mathrm{P}<0.05)$ lower than the values recorded at 13:00 $\mathrm{h}$ and 19:00 $\mathrm{h}$ (Table 3).

Table 3: Effect of age on diurnal variation in skin surface temperature $\left({ }^{\circ} \mathrm{C}\right)$ of rabbits during the early-rainy season

\begin{tabular}{llll}
\hline Hour of the day & Weaners & Growers & Adults \\
\hline $07: 00$ & $31.73 \pm 0.32^{\mathbf{a}, \mathbf{x}}$ & $31.46 \pm 0.36^{\mathbf{a , x}}$ & $33.84 \pm 0.56^{\mathbf{b}, \mathbf{x}}$ \\
$10: 00$ & $32.62 \pm 0.29^{\mathbf{a}}$ & $32.21 \pm 0.11^{\mathbf{a}, \mathbf{x}}$ & $33.97 \pm 0.59^{\mathbf{b}}$ \\
$13: 00$ & $34.53 \pm 0.35^{\mathbf{a}, \mathbf{y}}$ & $33.59 \pm 0.40^{\mathbf{a}, \mathbf{b}, \mathbf{y}}$ & $35.49 \pm 0.39^{\mathbf{a}, \mathbf{c}, \mathbf{y}}$ \\
$16: 00$ & $33.89 \pm 0.62^{\mathbf{a}, \mathbf{y}}$ & $34.13 \pm 0.34^{\mathbf{a}, \mathbf{y}}$ & $35.20 \pm 0.37^{\mathbf{a}}$ \\
$19: 00$ & $33.27 \pm 0.35^{\mathbf{a}, \mathbf{y}}$ & $32.88 \pm 0.21^{\mathbf{a ,}, \mathbf{y}}$ & $35.80 \pm 0.62^{\mathbf{b}, \mathbf{y}}$ \\
\hline \multicolumn{4}{c}{$\mathbf{a , b , \mathbf { c }}=$ row with different superscript letters are significantly different $(\mathbf{P}<0.05)$}
\end{tabular}


Effect age on diurnal variation in ear surface temperature $\left({ }^{\circ} \mathrm{C}\right)$ of rabbits

The ET values gradually increase at $07: 00 \mathrm{~h}$ and attained the highest value at 16:00 h regardless of the age group of rabbits. However, this was followed by a slight decrease at 19:00 $\mathrm{h}$ in all the group. The values recorded at $07: 00 \mathrm{~h}$ was significantly lower than the values at 13:00 $\mathrm{h}, 16: 00 \mathrm{~h}$ and
19:00 h (Table 4).

Overall mean RT, ST and ET clearly indicated that the adult values were significantly $(\mathrm{P}<0.001)$ higher than the values obtained in weaner or grower rabbits (Table 5). The meteorological parameters of RH negatively correlated with ET in all the age group of rabbits (Table 6).

Table 4: Effect of age on diurnal variation in ear surface temperature $\left({ }^{\circ} \mathrm{C}\right)$ of rabbits during the early-rainy season

\begin{tabular}{llll}
\hline Hour of the day & Weaners & Growers & Adults \\
\hline $07: 00$ & $31.91 \pm 0.39^{\mathbf{a}, \mathbf{x}}$ & $32.14 \pm 0.35^{\mathbf{a}, \mathbf{x}}$ & $33.54 \pm 0.39^{\mathbf{b}, \mathbf{x}}$ \\
$10: 00$ & $33.35 \pm 0.36^{\mathbf{y}}$ & $33.41 \pm 0.27^{\mathbf{y}}$ & $34.19 \pm 0.44$ \\
$13: 00$ & $34.18 \pm 0.30^{\mathbf{y}}$ & $34.29 \pm 0.25^{\mathbf{y}}$ & $35.06 \pm 0.27^{\mathbf{y}}$ \\
$16: 00$ & $34.56 \pm 0.34^{\mathbf{y}}$ & $35.24 \pm 0.34^{\mathbf{y}}$ & $34.96 \pm 0.29^{\mathbf{y}}$ \\
$19: 00$ & $33.39 \pm 0.53^{\mathbf{y}}$ & $33.50 \pm 0.39^{\mathbf{y}}$ & $34.31 \pm 0.46$ \\
\hline
\end{tabular}

$\overline{\mathrm{a}, \mathrm{b}}=$ row with different superscript letters are significantly different $(\mathrm{P}<0.05)$

$\mathrm{x}, \mathrm{y}=$ column with different superscript letters are significantly different $(\mathrm{P}<0.05)$

Table 5: Overall mean, minimum and maximum thermoregulatory responses $\left({ }^{\circ} \mathrm{C}\right)$ of rabbits during the early rainy-season

\begin{tabular}{llll}
\hline Parameters & Weaners & Growers & Adults \\
\hline Rectal temperature & $37.61 \pm 0.08^{\mathbf{a}}$ & $37.43 \pm 0.08^{\mathbf{a}}$ & $38.13 \pm 0.09^{\mathbf{b}}$ \\
& $(36.00-39.20)$ & $(35.70-38.60)$ & $(35.60-39.90)$ \\
Ear surface temperature & $33.48 \pm 0.20^{\mathbf{a}}$ & $33.72 \pm 0.19^{\mathbf{a}}$ & $34.41 \pm 0.18^{\mathbf{b}}$ \\
& $(29.40-36.20)$ & $(30.40-37.10)$ & $(31.40-37.90)$ \\
Skin surface temperature & $33.21 \pm 0.21^{\mathbf{a}}$ & $32.85 \pm 0.17^{\mathbf{a}}$ & $34.86 \pm 0.25^{\mathbf{b}}$ \\
& $(25.00-37.20)$ & $(29.30-36.90)$ & $(29.5-39.10)$ \\
\hline
\end{tabular}

$\mathrm{a}, \mathrm{b}=$ row with different superscript letters are significantly different $(\mathrm{P}<0.001)$

Table 6: Relationships between thermoregulatory responses and meteorological parameters

\begin{tabular}{|c|c|c|c|}
\hline Correlated parameters & Weaners & Growers & Adults \\
\hline Dry-bulb temperature and rectal temperature & $-0.071^{\mathrm{ns}}$ & $-0.335 * *$ & $-0.160^{\mathrm{ns}}$ \\
\hline Dry-bulb temperature and ear temperature & $0.656^{* * *}$ & $0.584 * * *$ & $0.642 * * *$ \\
\hline Dry-bulb temperature and skin temperature & $0.552 * * *$ & $0.686^{* * *}$ & $0.131^{\mathrm{ns}}$ \\
\hline Relative humidity and rectal temperature & $0.024^{\mathrm{ns}}$ & $0.151^{\text {ns }}$ & $0.138^{\mathrm{ns}}$ \\
\hline Relative humidity and ear temperature & $-0.591 * * *$ & $-0.504 * * *$ & $-0.520 * * *$ \\
\hline Relative humidity and skin temperature & $-0.490 * * *$ & $-0.570 * * *$ & $-0.030^{\mathrm{ns}}$ \\
\hline $\begin{array}{l}\text { Temperature-humidity index and rectal surface } \\
\text { temperature }\end{array}$ & $-0.127^{\mathrm{ns}}$ & $-0.339 * *$ & $-0.100^{\mathrm{ns}}$ \\
\hline $\begin{array}{l}\text { Temperature-humidity index and ear surface } \\
\text { temperature }\end{array}$ & $0.442 * * *$ & $0.624 * * *$ & $0.546 * * *$ \\
\hline $\begin{array}{l}\text { Temperature-humidity index and skin surface } \\
\text { temperature }\end{array}$ & $0.400 * * *$ & $0.710 * * *$ & $0.135^{\text {ns }}$ \\
\hline
\end{tabular}




\section{Age-dependent changes in diurnal thermoregulatory responses of rabbits}

\section{Discussion}

The maximum ambient temperature and relative humidity recorded in the early rainy season in the present study fell above the thermoneutral zone established for rabbits (21-25 $\left.{ }^{\circ} \mathrm{C}\right)$ (Marai et al., 2002), suggesting that the rabbits were subjected to heat stress during the early-rainy season. Results of the present study revealed diurnal fluctuations in mean rectal temperature, ear and skin surface temperatures, irrespective of the age of the rabbit. In the present study, the highest mean rectal temperature was obtained in the morning relative to other hours of the day in all the groups of rabbits indicates in part that the prevailing ambient temperature did not have a marked effect on the rectal temperature of the rabbit during the afternoon, presumably that the thermoregulatory mechanisms of the rabbits were able to maintain thermal homeostasis of the rabbits during the afternoon and early evening hours. This finding is in consonant with report of Zeferino et al. (2011), that reported a nonsignificant effect of different ambient temperatures in two breeds of rabbits in controlled chambers. Furthermore, the highest rectal temperature recorded during the morning hour may be due to highest prevailing relative humidity recorded during the morning hour in the present study, that affected the rabbits from dissipating body heat through the skin and ear surfaces as exemplified by the lowest skin and ear surface temperatures in all the groups of rabbits during the morning hours. This buttresses the fact that ambient temperature and relative humidity appear to play a greater role in the tropics in regulating circadian rhythms (Vathana et al., 2002; Yaqub et al., 2017). Rabbits are sensitive to low relative humidity but not to very high humidity. However, when the AT is too high or close to the rabbit core temperature, a high RH becomes a problem. The process of heat dissipation becomes ineffective as it dependent on prevailing $\mathrm{RH}$. Unfortunately, this is a common situation in tropical climate during the early-rainy season. Dzenda et al. (2011) investigated the effect of diurnal, seasonal and sex on rectal temperature, reported that relative humidity has a stronger influence on the impact of ambient temperature on rectal temperature of African giant rats. The significantly higher rectal temperature in adult rabbits relative to the weaner rabbits may suggest that the rabbits were more sensitive to the prevailing meteorological parameters with age (Zeferino et al, 2011, Fadare 2015). Added to the meteorological factors that influence body temperature are the animal factors of age, sex, body weight and metabolic rate (Keim et al., 2002; Dzenda et al., 2011). In rabbits, the ear plays a pivotal role in thermoregulation because they represent about $12 \%$ of the body surface area (Zeferino et al., 2011) with largest arteriovenous anastomotic arrangement, facilitating heat exchange through a counter-current system (Brewer and Cruise, 1994). In the current study, the ear surface and skin temperatures are within the range reported by Zeferino et al. (2011). The statistically significant diurnal fluctuations in mean ear and skin temperatures obviously indicate that the rabbits employed these organs in offsetting the body heat load during the hot afternoon hours. This point is supported in part by a stronger statistically significant positive correlation between the prevailing ambient temperature and the ear and skin surface temperatures. This showed that the prevailing ambient temperature increased with hours of the day, it induces changes in sympathetic activity that resulted in redistribution of blood flow from the viscera to the periphery to enable dissipation of heat from the body (Lublin and Wolfeson, 1996; Cham and Badoer, 2008). However, the RH negatively correlated with ear and skin temperatures, 
which implies an hinderance to efficient heat dissipation as the prevailing $\mathrm{RH}$ increases. Hence, an increase in heat accumulation in body and probably responsible for the highest RT recorded at 07:00 $\mathrm{h}$ in this study. Adequate ventilation in rabbit house may help in reduce the $\mathrm{RH}$ and invariably improving the capacity of the to dissipate heat the environment.

\section{Conclusions}

There was age-dependent effect on diurnal thermoregulatory responses of rabbits during the early-rainy season. The prevailing meteorological parameters, most especially the RH negatively impacted on heat dissipation ability of the rabbits during the early-rainy season. It is therefore recommended that adequate ventilation should be provided in rabbit house to reduce the negative impact of high relative humidity on heat dissipation ability of rabbits during the early-rainy season. Rabbit farmers should also take into cognizance of age-dependent thermoregulatory mechanisms of heat dissipation in order to achieve optimal productivity.

\section{References}

Amici, A., Canganella, F. and Bevilacqua, L. 1998. Effects of high ambient temperatures in rabbits: metabolic changes, caecal fermentation and bacterial flora. World Rabbit Science, 6: 319324.

Ayo, J. O., Dzenda, T., Oladele, S. B. and Adaudi, A. O. 2006. Diurnal and individual fluctuations in rectal temperature of the rabbits during the hot-dry season. Proceedings $31^{\text {st }}$ Annual Scientific Conference of Nigerian Society for Animal Production, March 12-15, 2006, Kano, Nigeria, pp. 7073.
Barbosa, O. R., Scapinello, C., Martins, E. N., Mendes, L. D. V., Sugohara, A. and Saito, E. Y. 1992. Desempenho de coelhos da raça Nova Zelândia Branco, criados em diferentestipos deinstalações, $\mathrm{d} \mathrm{u} \mathrm{r}$ a $\mathrm{n} \mathrm{t}$ e a s estações de verão e inverno. 1 Temperatura corpora 1 , freqüência respiratória, consumo deração, ganho de peso e conversão a $1 \mathrm{im} \mathrm{entar.} \mathrm{Revista.}$ Brasileira de Zootecnia, 21: 779-786.

Brewer, N. R. aand Cruise, L. J. 1994. Physiology. In: Manning, P.J., Ringler, D.H., Newcomer, C.E. (Eds.), The Biology of the Laboratory Rabbit. Academic Press, New York, pp. 63-70.

Cham, J. L. and Badoer, E. 2008. Hypothalamic paraventricular nucleus is critical for renal vasoconstriction elicited by elevation in body temperature. American Journal of PysiologyRenal Pysiology, 294: 309-315.

Dzenda, T., Ayo, J. O., Lakpini; C. A. M and Adelaiye, A. B 2011. Diurnal, seasonal and sex variations in rectal temperature of African giant rats (Cricetomys gambianus, waterhouse). Journal of Thermal Biology, 36: 255-263.

Fadare, A. O. 2015. Thermo physiological traits of Californian, New Zealand White Havana black and palamino brown rabbits raised in humid tropics. Journal of Biology, Agriculture and Healthcare, 5(3): 204-210.

Ferraz, P. F. P., Hernandez-Julio, Y. F., Ferraz, G. A. S., Moura, R. S., Rossi, G., Saraz, J.A. O . a n d Barbari, M. 2019. Decision trees for predicting the physiological responses of rabbits. 
Animals, doi:10.3390/ani9110994.

Hermes, J. H., Ahmed, B. M., Khalil, M. H., Salah, M. S. and Al-Homidan, A.A. 1999 . G r o w th performance, nutrients utilization and carcass traits of growing Californian rabbits raised under different ambient temperatures. Egyptian Journal of Rabbit Science, 9: 117-138.

Lukefahr, S. D. and Ruiz-Feria, C. A. 2003. Rabbit growth performance in a subtropical and semi-arid environment: effects of fur dipping, ear-length, and body temperature. Livestock Research for Rural Development, 15(2).

Marai, I. F. M., Habeeb, A. A. M. and Gad, A. E. 2002. Rabbit's productive, reproductive and physiological traits as affected by heat stress (a review). Livestock Production Science, 78: 71-90.
Ogunjimi, L. A. O., Ogunwade, G. A. and Osunade, J. A. 2008. Influence of building environment on rabbit weight gain, feed efficiency, rectal temperature and respiration rate in humid tropical climate of Southwestern Nigeria. Agriculture Engineering International: the CIGR Ejournal. Manuscript BC.07008. Volume X January, 2008.

Yaqub, L. S., Ayo, J. O., Kawu, M. U. and Rekwot, P. I. 2017. Diurnal thermoregulatory responses in pregnant Yankasa ewes to the dry season in a tropical Savannah. Tropical Animal Health and Production, 49: 1243-1252.

Received: $12^{\text {th }}$ December, 2020 Accepted: $26^{\text {th }}$ February, 2021 